\title{
Miskomunikasi Visual dalam Poster Instagram Story acara Gelar Cipta Tata Rias 2019: Indonesian Folklore
}

\author{
Damara Alif Pradipta \\ Ilustrator \\ Pascasarjana ISI Yogyakarta \\ karateka.yoith@gmail.com
}

\begin{abstract}
Visual Communication Design is a science that uses the management of visual elements in the design process. Sometimes there are problems in designing a DKV work. One of these problems is the presence of visual miscommunication which means there is a lack synchronization between the message and the visual elements that exist. In this paper, we discuss the visual miscommunication contained in the Poster story Instagram from the event named "Gelar Cipta Tata Rias 2019: Indonesian Folklore" which held by the 2015 class of Cosmetology Department, Surabaya State University. In discussing this poster, the author used the art critique method and got the result that there was a lack of synchronization between the visual elements of the poster and the theme of the event which themed "Indonesian Folklore".
\end{abstract}

Keywords: visual communication design, misscommunication, poster, cosmetology, critics.

Relevance to Visual Communication Design Practice: In this paper, audience can learn about visual miscommunication in poster design, so that audience which willing to design a poster can consider various aspect such as communication, appropriateness, strategies and not only working with good visual.

\section{PENDAHULUAN}

Desain Komunikasi Visual (selanjutnya disebut DKV) merupakan suatu ilmu yang menghubungkan antara ilmu desain, ilmu komunikasi dan visual, dalam buku Communication Design: Principles, Methods, and Practice yang ditulis oleh Jorge Frascara mengatakan bahwa DKV merupakan sebuah kegiatan atau aktifitas yang memahami, memprogram, memproyeksikan dan merealisasikan komunikasi visual yang biasanya diproduksi melalui sarana industri dan ditujukan untuk menyiarkan atau menyempaikan pesan khusus ke sektor publik tertentu (Frascara, 2004:02).

Dapat disimpulkan bahwa DKV merupakan suatu ilmu pengelolaan, perencanaan terstruktur yang matang untuk membentuk sebuah komunikasi yang dapat mempengaruhi khalayak sasaran, baik segi keilmuan, perilaku sehari-hari, kebiasaan bahkan pengambilan keputusan melalui suatu pengelolaan dan pengorganisasian elemen-elemen visual seperti gambar dan tipografi.

Wilayah kerja seorang desainer komunikasi visual juga harus berkutat seputar interpretasi, pengorganisasian dari pesan visual, selain itu desainer komunikasi visual juga harus memikirkan kefektifan, kelayakan, keindahan dan ke-ekonomisan sebuah pesan (Frascara, 2004:03).

Oleh karena itu kerja seorang desainer komunikasi visual tidak hanya memikirkan sisi keindahan dari visual saja, akan tetapi kerja desainer komunikasi visual juga 
melampaui segi estetis dari sebuah visual tapi juga ada sebuah usaha untuk merencanakan, merancang, mengevaluasi, memproduksi sebuah komunikasi yang dibentuk dengan elemen-elemen visual untuk menciptakan sebuah komunikasi yang layak dan efektif sesuai dengan khalayak sasaran.

Oleh karena itu desainer komunikasi visual haruslah mempunyai wawasan pengetahuan yang luas dari berbagai bidang keilmuan seperti sejarah, antropologi, sosiologi dan psikologi dan tidak hanya berkutat dalam segi teknis seperti "bagaimana caranya menciptakan visual desain yang menarik", " ah aku pake gaya visual seperti in saja, karena aku suka gaya ini !", sehingga nantinya desainer kan memiliki wawasan yang kaya dan dapat memahami khalayak sasaran serta dapat mengerti kebutuhan, bukan hanya keinginan dan mengetahui aksi atau perbuatan yang harus dilakukan untuk menciptakan komunikasi yang efektif berbekal ilmu dari berbagai bidang keilmuan yang dipelajari.

Dari beberapa penjelasan serta keterangan diatas maka keilmuan DKV merupakan ilmu yang memiliki solusi untuk memcahkan masalah khususnya masalah komunikasi dengan menggunakan media perantara pengorganisasian unsur-unsur visual. Pernyataan penulis juga diperkuat oleh pernyataan Sumbo Tinarbuko (2015) dalam bukunya yang berjudul "DEKAVE: Desain Komunikasi Visual - Penanda Zaman Masyarakat Global", yang mengatakan bahwa DKV merupakan merupakan sebuah disiplin yang menggunakan rupa dan konsep komunikasi sebagai upaya untuk memecahkan masalah.
Dari sini seorang desainer komunikasi visual juga memiliki peran yang besar dalam merubah konstruksi sosial yang ada dalam masyarakat. Sebagai contoh penggunaan DKV dalam berbagai propaganda yang terjadi dari sejak era Nazi hingga era hari ini seperti banyaknya konstruksi-konstruksi sosial yang dibangun melalui media DKV untuk merubah pola pikir masyarakat dari hal yang satu ke hal yang lainnya. Seperti contohnya adalah ujaran kebencian dan berita bohong yang terjadi di Indonesia belakangan ini. Banyak masyarakat yang terkonstruksi oleh media DKV yang memiliki kandungan ujaran kebencian dan berita bohong tersebut dan akhirnya dapat menimbulkan perpecahan dan konflik sosial yang dapat dilihat contohnya seperti konflik pada tanggal 22 Mei 2019 di Jakarta. Salah satu contoh penerapan DKV yang di salah gunakan untuk menyebarkan ujaran kebencian dan menyebarkan kontroversi adalah sebagai contoh seperti gambar dibawah ini:

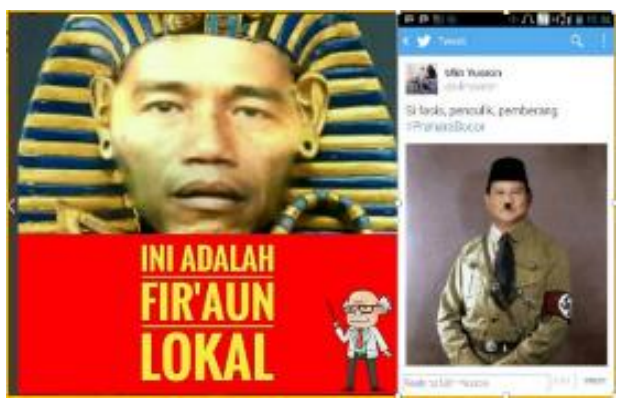

Gambar 1 Media DKV yang digunakan untuk menyebarkan ujaran kebencian.

Sumber: instagram @prof.tjohkohwie dan google 


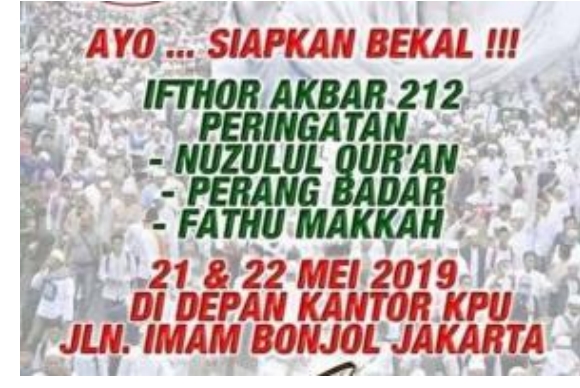

Gambar 2 Media DKV yang digunakan sebagai media kontroversi dan ajakan untuk melakukan People Power alih-alih dibalut dengan agama. Sumber: www. Google.com

Dapat diartikan juga bahwa DKV merupakan ilmu yang memiliki dua mata pisau, disisi lain DKV juga dapat memecahkan masalah, namun disisi lain juga DKV juga dapat menimbulkan masalah. Oleh karena itu, seorang desainer komunikasi visual merupakan pekerjaan yang memikul tanggung jawab besar bagi kelangsungan umat manusia. Apabila sebuah desain yang dirancang memiliki miskomunikasi dan hal tersebut digaungkan terus menerus maka lama kelamaan akan terbentuk konstruksi sosial dan hal tersebut dapat menjadi dosa sosial bagi para desainer komunikasi visual.

Poster merupakan bagian dari media DKV yang digunakan untuk menginformasikan, mempromosikan dan menyampaikan pesan akan sesuatu kepada masyarakat terutama khalayak sasaran. Menurut Kusrianto(2009: 338), poster di identifikasikan sebagai salah satu bagian dari seni grafis yang memiliki gaya, aliran, maupun trend tersendiri yang tidak lepas dari penguasaan teknologi serta gaya hidup oleh suatu zaman.

Poster juga memiliki definisi lain yaitu sebuah publikasi berbentuk dua dimensional dan satu muka, digunakan untuk menyampaikan pesan yang berupa informasi, data, jadwal, atau penawaran maupun promosi. Poster merupakan media yang digunakan untuk menyampaikan informasi untuk orang-orang yang bergerak atau dinamis, sehingga poster haruslah memiliki tampilan visual yang menarik dan mampu menarik perhatian publik seraya menyampaikan informasi yang mudah dicerna pembaca dalam hitungan detik (Supriono, 2010: 158).

Seiring berkembangnya waktu, poster yang awalnya di identikan dengan media fisik dua dimensi yang ditempelkan di dmedia datar, kini seiring berkembangnya zaman, bentuk poster tidak hanya berbentuk media fisik saja. Poster hari ini berkembang merambah dunia digital, tentunya hal ini dilakukan karena menyesuaikan perkembangan zaman yang mana masyarakatnya mulai banyak berinteraksi melalui dunia digital seperti contoh internet, sehingga poster yang disebar melalui media digital dinilai merupakan strategi yang terbaik.

Poster-poster yang berada di dunia digital atau bisa disebut dunia maya biasanya disebar di media media yang banyak diakses oleh masyarakat internet, seperti contohnya adalah disebarnya posterposter di media-media sosial seperti Facebook, Whatsapp, Twitter dan Instagram. Salah satu event atau acara yang memanfaatkan media sosial untuk mempromosikan kegiatan adalah acara unjik karya yang digelar oleh mahasiswa jurusan Tata Rias dari Universitas Negeri Surabaya (setelah ini disebut Unesa) yang berjudul Gelar Cipta Tata Rias dengan mengusung tema "Indonesian Folklore". 


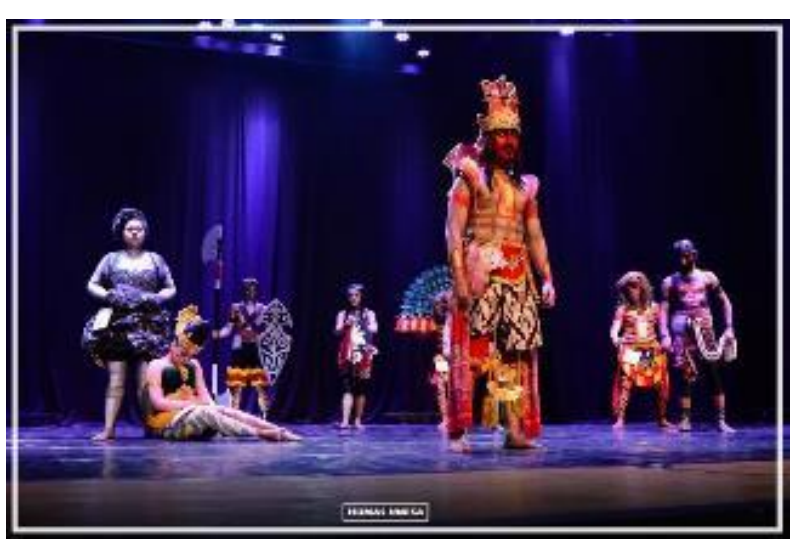

Gambar 3 Cuplikan susasana acara Gelar Cipta Tata Rias 2019.

Sumber: www.unesa.ac.id

Salah satu usaha para mahasiswa jurusan Tata Rias Unesa dalam mempromosikan acara tersebut melalui media sosial adalah dengan mempromosikan melalui akun instagram mereka yang memiliki nama akun @tatariasunesa Beberapa contoh poster untuk promosi acara ini adalah dengan mengunggah poster pada feed atau postingan dari akun tersebut.

Selain itu akun @tatariasunesa juga mempromosikan poster Indonesian Folklore melalui media Instagram Story. Namun dalam penerapan dari poster dengan media Instagram Story tersebut memiliki permasalahan komunikasi visual yang menurut penulis layak dan sangat penting untuk dibahas, sehingga nantinya dalam tulisan ini penulis merumuskan beberapa pertanyaan penelitian yang jika dijabarkan adalah sebagai berikut:

1. Permasalahan komunikasi visual apa yang ada pada Poster Instagram Story dari acara Gelar cipta Karya: Indonsian Folklore?
Dalam menjawab beberapa pertanyaan penelitian tersebut, maka penulis menggunakan metode kritik seni dengan beberapa unsur yaitu dekspripsi, analisis formal, interpretasi dan judgement. Diharap dengan metode ini penulis dapat menjawab beberapa pertanyaan penelitian yang dibuat diatas.

\section{PEMBAHASAN}

Gelar Cipta Tata Rias merupakan nama dari acara fashion show mahasiswa Jurusan Tata Rias Unesa yang diadakan setiap tahun. Acara Gelar Cipta Tata Rias merupakan acara sebagai unjuk karya mahasiswa Jurusan Tata Rias Unesa. Menurut pengalaman penulis, acara ini dilaksanakan di tempat-tempat yang berbeda setiap tahunnya, ada yang pernah dilaksanakan di Surabaya Night Carnival hingga ada yang pernah dilaksanakan di Gedung Balai Pemuda Surabaya.

Dalam kesempatan kali ini, acara Gelar Cipta Tata Rias diselengarakan diselenggarakan di Gedung Balai Budaya lantai 2, Kompleks Balai Pemuda Surabaya. mahasiswa prodi S1 Pendidikan Tata Rias angkatan 2015, Jurusan Pendidikan Kesejahteraan Keluarga (PKK), Fakultas Teknik (FT) (ww.unesa.ac.id, 2019). 


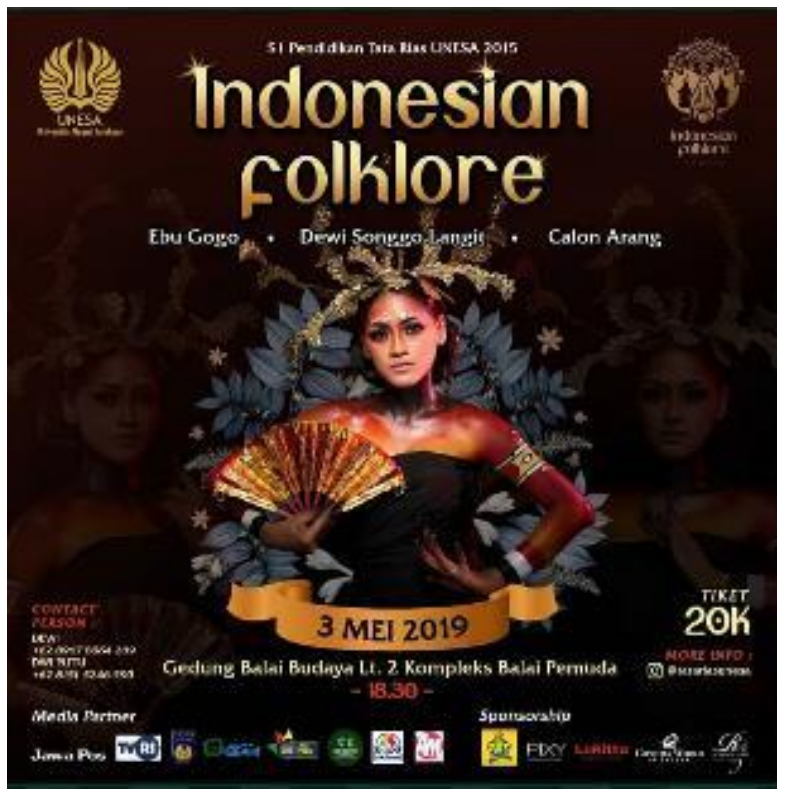

Gambar 4 Poster Feed Instagram Indonesian Folklore.

Sumber : Instagram @tatariasunesa

Menurut Yunita Novia Maharani selaku ketua pelaksana dalam unesa.ac.id mengatakan, jika konsep dan kemasan dalam gelar cipta tahun ini dikemas berbeda dengan tahun sebelumnya. Dalam tahun ini, 58 mahasiswa dan 58 aktor memamerkan seni make up dan body painting yang disajikan melalui teatrikal drama. Drama yang diangkat juga merupakan cerita rakyat asli Indonesia yang diambil dari tiga daerah, yakni cerita Dewi Songgo Langit dari Ponorogo, Calon Arang dari Bali, dan Ebu Gogo dari Flores. Yunita juga menjelaskan jika gelar cipta tersebut memakan dana sebesar 200 juta yang didapat dari iuran mahasiswa.

Dapat disimpulkan bahwa acara Gelar Cipta Tata Rias 2019 dengan tema Indonesian Folklore merupakan acara yang sangat besar dan megah karena menghabiskan dana yang cukup besar. Sudah pasti acara tersebut di rancangan sedemikian rupa agar banyak pengunjung yang datang untuk mengapresiasi acara tersebut.

Beberapa strategi yang dilakukan untuk menarik pengunjung agar datang menghadiri dan mengapresiasi acara tersbut adalah dengan adanya media informasi. Beberapa cara yang dilakukan acara tersebut sesuai dengan bidang DKV adalah dengan menyebarkan Poster. Poster yang disebarkan dapat berupa poster fisik dan poster digital. Dalam tulisan iki akan dibahas mengenai poster digital yang di unggah oleh penyelenggara di akun Instagram @tatariasunesa. Ada dua jenis poster digital yang diunggah, yaitu poster yang diunggah di Instagram Feed seperti gambar dibawah ini:

Selain poster yang diunggah melalui Instagram feed, akun Instagram @tatariasunesa juga memanfaatkan fasilitas Instagram yaitu fasilitas Instagram Story. Fasilitas ini memungkinkan pengguna untuk membuat postingan yang terkesan sebgai diary dan bersifat tidak permanen karena hanya bertahan 48 jam saja. Dalam postingan Instagram story dari akun @tatariasunesa inilah yang nantinya akan dibahas dan di kritik penulis dalam tulisan ini. Berikut ini adalah gambar dari postingan Instagram story dari akun Instagram $@$ tatariasunesa: 


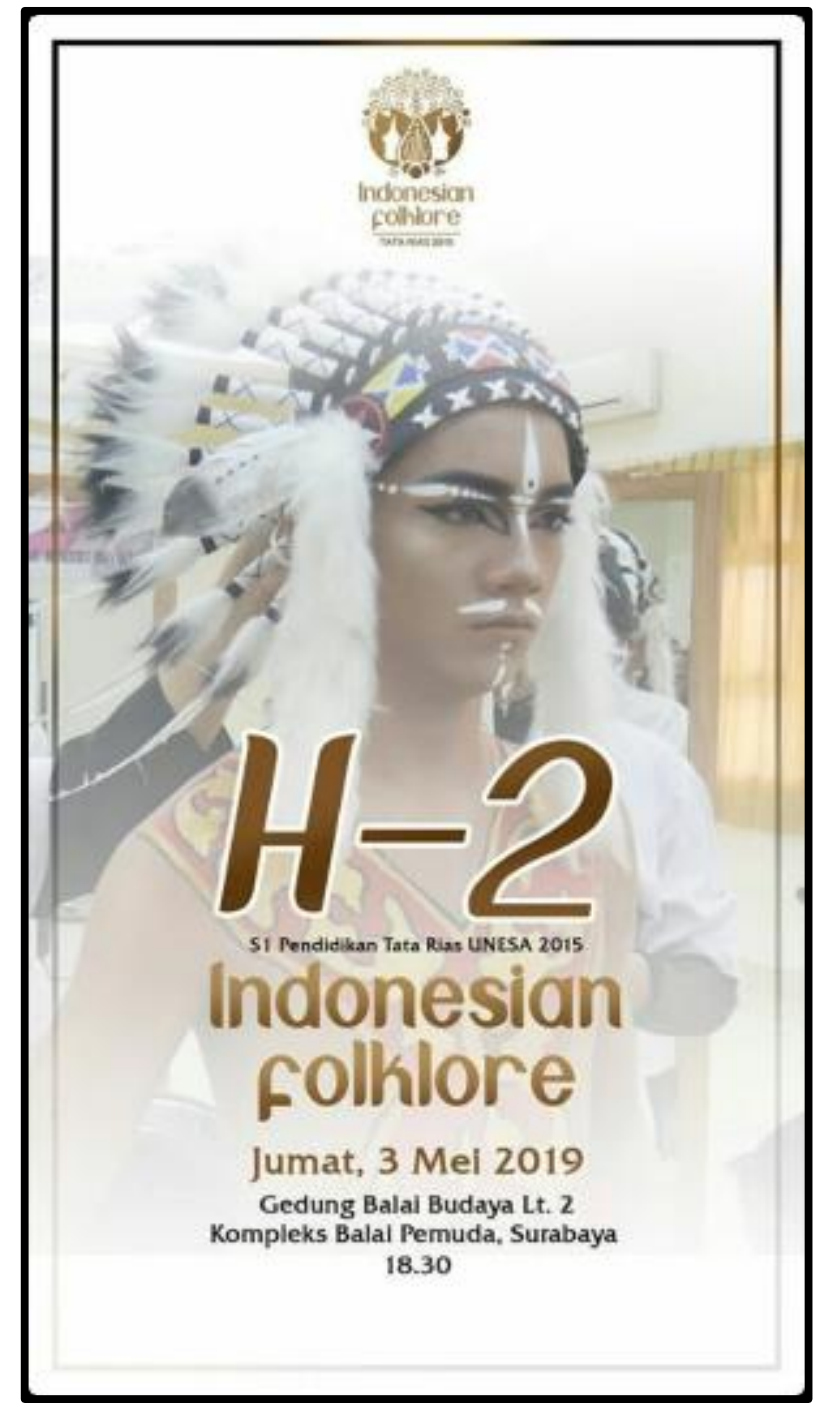

Gambar 5 Poster Story Instagram Indonesian Folklore

Sumber : Instagram @tatariasunesa

Untuk melakukan kritik terhadap karya seni atau dalam kasus ini adalah karya desain yang berhubungan dengan visual dan seni rupa, maka menurut Bahari (2008:9) biasanya terdapat unsur-unsur kritik seni berupa deskripsi, analisis formal, interpretasi dan evaluasi terhadapkarya seni atau dalam kasus ini karya desain yang diciptakan. Sistermatika dalam penggunaan unsur-unsur kritik seni tersebut dapat dilakukan secara berurutan maupun secara acak, tergantung dan disesuaikan oleh pokok bahasan yang akan diangkat dalam sebuah kritik seni. Dalam penulisan ini, penulis memilih untuk menggunakan unsur-unsur kritik seni secara berurutan, hal ini bertujuan untuk mempermudah pembaca yang baru dalam perilhal dunia kritik seni.

Dalam pembahasan mengenai Poster acara Gelar Cipta Tata Rias 2019: Indonesian Folklore di story Instagram milik akun @tatariasunesa, penulis harus mendeskripsikan terlebih dahulu mengenai poster tersebut, hal ini bertujuan agar pembaca dapat membangun bayangan secara visual atau imaji bagi pembaca deskripsi tersebut. Adapun dalam hal ini deksripsi memiliki arti sebuah penjelasan mengenai apapun yang tampak secara visual dalam karya desain tersebut.

Dalam deksprisi poster story Instagram ini, hal pertama yang dibahas adalah mengenai ukuran dari poster tersebut. Poster tersebut memiliki ukuran yang sesuai dengan layar ponsel pintar dan disesuaikan dengan ukuran standar ukuran story Instagram yaitu dengan ukuran 16:9, atau bisa dibilang 16 banding 9. Kemudian pada unsur-unsur visual pada poster tersebut adalah bahwa didalam poster tersebut memiliki dua elemen pendukung, yaitu elemen grafis dan elemen teks atau tipografi.

Pertama-tama yang akan dibahas adalah elemen tipografi dari karya poster tersebut. elemen tipografi merupakan elemen yang tidak bisa dipisahkan dari sebuah karya poster, karena poster pada umumnya berfungsi untuk memberikan sebuah informasi, kemudian agar informasi tersebut tidak menimbulkan bias maka diberikannya elemen tipografi agar khalayak sasaran dapat menyerap informasi dengan 
jelas dan tepat sasaran Deskripsi mengenai elemen tipografi akan dijabarkan secara urutan secara vertikal dari atas ke bawah.

Elemen-elemen tipografi dari poster tersebut adalah:

1. Pada bagian ini terdapat huruf yang ukurannya cukup besar membentuk kata "H-2", ukuran huruf tersebut cukup besar hingga terlihat mendominasi elemen tpografi lainnya. Warna dari huruf tersebut adalah warna coklat dekat outline berwarna putih. Gaya penulisan huruf tersebut dibuat dengan gaya tulisan miring atau disebut juga dengan italic.

2. Bagian selanjutnya merupakan barisan huruf yang membentuk kata-kata dengan tulisan "S1 Pendidikan Tata rias UNESA 2019". Ukuran tipografi ini memiliki ukuran terkecil diantara elem tipografi lainnya dalam poster ini dan tulisan ini memiliki warna teks berwarna hitam.

3. Bagian selanjutnya merupakan elemen tipografi yang memiliki tulisan "Indonesian folklore". Elemen tipografi yang satu ini memiliki ukuran yang besar namun tidak lebih besar dari elemen tipografi urutan nomor 1. Elemen tipografi ini memiliki warna yang bersifat gradasi dengan warna coklat tua di bagian bawah teks dan warna coklat muda pada bagian atas teks tersebut

4. Elemen tipografi selanjutnya merupakan teks dengan tulisan "Jum'at, 3 Mei 2019”. Gaya teks ini berwarna coklat tua dan serupa dengan warna tipografi dari elemen tipografi bagian 1 .

5. Bagian elemen tipografi yang terakhir berada di bagian paling bawah sendiri dari semua elemen tipografi. Tulisan dari teks tersebut bertuliskan "Gedung Balai Budaya Lt.2 Kompleks Balai Pemuda, Surabaya 18.30. Warna dari teks tersebut adalah warna hitam.

Bagian selanjutnya yang akan dibahas adalah elemen grafis dari poster story Instagram tersebut. Dari pengamatan penulis terhadap poster tersebut, terdapat tiga elemen grafis yang ada yaitu:

1. Di bagian tepi dari poster tersebut, terdapat elemen grafis berupa persegi panjang berupa sebuah outline garis yang ada di bagian tepi poster. Adapun garis tersebut berwarna hitam dengan efek gradasi transparan yang dimulai dari bawah ke atas.

2. Pada bagian atas poster terdapat sebuah logo dari acara Indonesian Folklore. Logo dari acara tersebut bergambarkan dua wajah seorang wanita menghadang samping dengan arah berlawanan, dan terdapat ornamen-ornamen bunga seperti gaya visual mandala yang berada di atas wajah kedua wanita tersebut. kemudian di bagian bawah gambar dari logo tersebut terdapat sebuah tulisan dengan tulisan "Indonesian folklore" dengan warna coklat dengan gaya gradasi dari coklat muda ke coklat tua.

3. Kemudian selanjutnya adalah elemen grafis yang berada di tengah poster story Instagram tersebut. Elemen grafis tersebut berupa model berjenis kelamin pria yang mengenakan sebuah kostum dan pada wajah pria tersebut terdapat beberapa garis-garis berwana putih yang ditujukan untuk menghias wajah dan posisi kepala pria tersebut menghadap ke kanan. Model pria tersebut juga terlihat memakai perhiasan kepala dengan banyak bulu burung yang ditempelkan. Bentuk dari hiasan kepala dan ornamen dari model pria terlihat sama seperti hiasan kepala suku asli Amerika yaitu suku Indian. Adapun 
hiasan kepala asli suku Indian tersebut seperti gambar dibawah ini:

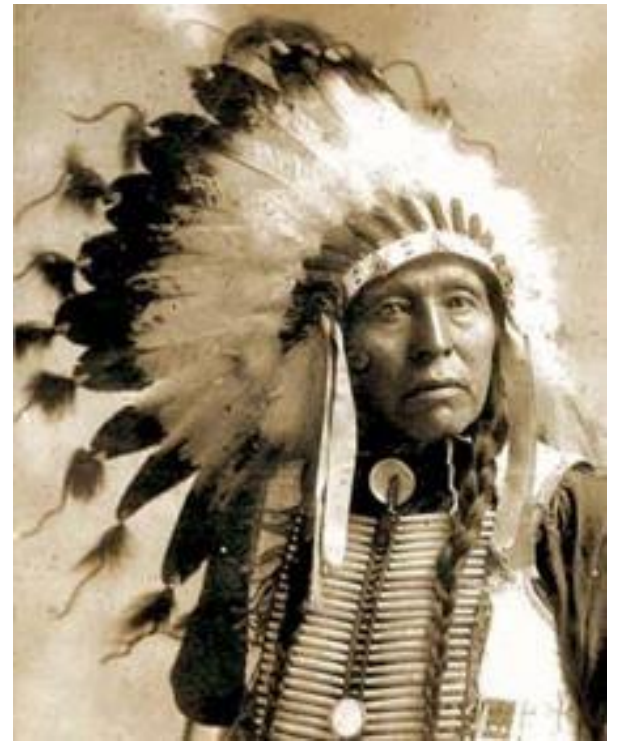

Gambar 6 Hiasan kepala suku Indian. Sumber Gambar: www.google.com

Langkah selanjutnya adalah melakukan analisis formal dari poster tersebut. Pada tahap ini, mencoba untuk menjelaskan objek yang dikritik dengan dukungan beberapa data yang tampak secara visual. Proses analisis formal dapat dimulai dengan cara menganalis objek secara keseluruhan mengenai kualitas unsur-unsur visual kemudian dianalisis bagian demi bagian, seperti menjelaskan tata cara pengorganisasian unsur-unsur elementer secara kesnirupaan seperti kualitas garis, bidang, warna dan tekstur (Bahari, 2008:11)

Pada poster story Instagram acara Indonesian Folklore tersebut, penempatan objek-objek visual baik elemen tipografi dan elemen grafis ditata sedemikian rupa dan memiliki alur baca yang bertempatan dari atas ke bawah, sehingga objek visual seperti elemen tipografi dan elemen grafis terlihat berkesinambungan dan terlihat seimbang.
Selain elemen visual poster tersebut juga memiliki elemen tipografi yang diletakan pada bagian tengah ke bawah. Poster ini memiliki keseimbangan yang simetris yang mana poster dirancang untuk dibaca dari atas ke bawah. Adapun elemenelemen tipografi memiliki ukuran yang beragam, ukuran dari berbagai elemen tipografi tersebut disesuaikan, yang dibuat lebih besar adalah merupakan hal yang ditekan kan dan yang diharapkan dibaca tersebih dahulu ketika komunikan membaca poster ini.

Setelah langkah menganalisis bagianbagian formal berupa objek-objek visual, hal yang perlu dilakukan selanjutnya dalam tahap kritik seni adalah melakukan interpretasi. Menurut Bahari (2008:12) Interpretasi merupakan tahap menafsirkan hal-hal yang terdapat dibalik sebuah karya, dan menafsirkan makna, pesan, dan nilai yang dikandungnya. Setiap penafsiran dapat mengungkan hal-hal yang berhubungan dengan pernyataan dibalik struktur bentuk, misal unsur psikologis pencipta, latar belakang sosial budaya, gagasan, abstraksi, pendirian, pertimbangan, hasrat, kepercayaan serta pengalaman tertentu senimannya.

Dalam tahap interpretasi dari Poster story Instagram dari acara Gelar Cipta Tata Rias 2019: Indonesian Folklore, tata letak atau layout dibuat dengan alur dari atas kebawah dan dibuat simetris sehingga terkesan memang untuk keefesienan dan kecepatan dalam penyerapan informasi. Tulisan dari H-2 dan Indonesian Folklore dibuat besar untuk menarik perhatian pengguna media sosial yang notabene selalu cepat dalam mengakses informasi yang terdapat di media sosial. Kemudian pada 
gaya visual dari poster terkesan adanya dominasi warna putih, sehingga kesan visual yang ditimbulkan dari poster tersebut adalah adanya kesan minimalis, kesan yang seperti mengawang-awang .

Kesan minimalis ini juga di buat agar pesan yang ingin disampaikan dapat tersampaikan dengan baik sehingga meminimalisir gangguan-gangguan visual yang menyebabkan informasi menjadi kabur.

Pemilihan elemen grafis berupa model dengan riasan mirip dengan riasan suku Indian Amerika dipilih karena gaya-gaya tersebut sedang naik daun dalam fashion. Dan hal ini dirasa memang untuk menarim perhatian pengguna media sosial agar datang di acara tersebut.

Sehingga secara keseluruhan interpretasi yang muncul adalah bahwa masyarakat yang melihat poster dari story Instagram tersebut akan mengira bahwa riasan kepala dan riasan wajah yang notabene dari suku asli Indian tersebut adalah bagian dari budaya Indonesia karena adanya tulisan "Indonesian Folklore".

Kemudian setelah tahap interpretasi, tahap selanjutnya dalam sebuah kritik seni adalah tahap evaluasi atau penilaian. Menurut Bahari(2008:13) tahap penilaian bukan seperti menilai siswa sekolah seperti nilai 80, 85, 90 dan seterusnya, namun menilai sebuah karya seni adalah menilai derajat karya tersebut, kualitas dari visual yang dihasilkan atau juga dari penyampaian pesan dari seorang seniman dari karya ke orang-orang yang melihat.

Dalam karya poster story Insrtagram acara Gelar Cipta Tata Rias 2019 : Indonesian Folklore, secara visual dan teknik poster tersebut sudah memenuhi kriteria DKV dalam penyampaian pesan. Dapat dilihat dari pemilihan gaya visual yang terkesan sederhana tidak terlalu memiliki banyak warna-warna yang kontras namun juga mengutamakan kejelasan penulisan atau elemen tipografi. Kemudian juga adanya keseimbangan antara objek-objek visual seperti elemen grafis dan elemen tipografi yang jika dibandingkan memiliki proporsi yang sama.

Namun waualupun perbandingannya sama, disini yang dianggap sama bukanlah dari ukuran seberapa besar objek visual tersebut bersanding, namun yang dititik beratkan penulis disini adalah nilai akan sebuah pesan yang disampaikan dan menurut penilaian penulis, karya poster tersebut memiliki bobot atau nilai yang seimbang antara elemen grafis dan elemen tipografi.

Selain itu juga poster ini dianggap menarik karena adanya ruang kosong atau white-space yang dimanfaatkan dalam poster ini. Ruang kosong dalam poster ini berfungsi agar pengorganisasian antar elemen terlihat seimbang dan agar tidak terlihat sesak, selain itu juga ruang kosong atau white space juga bertujuan agar dapat memanjakan mata dan agar penikmat poster fokus terhadap pesan atau informasi yang diberikan.

Dari penilaian penulis terhadap karya poster ini, dapat diambil kesimpulan bahwa desainer yang merancang poster ini memiliki skill desain dan teknik dalam pengorganisasian unsur visual yang baik, dari segi visual dapat dilihat bahwa desainer banyak memiliki proyek-proyek sejenis. Namun yang menjadi masalah dalam tulisan ini adalah bukan masalah pengorganisasian visual atau teknik dari poster tersebut. 
dalam kritik seni dengan bidang ilmu DKV, visual merupakan hal yang penting namun bukan sebagai penentu utama dalam keberhasilan karya desain, namun juga harus dipertimbangkan dan diperhitungkan masalah komunikasi juga. Bagaimana tanggapan masyarakat, interpretasi masyarakat terhadap pesan berupa visual juga harus dipertimbangkan, dikarenakan DKV dekat dengan peorganisasian visual dan jikalau terdapat pengorganisasian visual yang tidak tepat maka akan terjadi ketidakcocokan antara pesan dengan visual, sehingga akan terjadi yang namanya "Miskomunikasi Visual".

Dalam poster ini yang menjadi masalah adalah pemilihan model atau elemen grafis dan diletakan jelas dalam poster tersebut. Menurut penulis, pemilihan elemen grafis berupa model dengan kostum layaknya suku Indian asli Amerika bukanlah hal yang tepat, dan bahkan dapat dibilang "nggak nyambung" karena notabene acara tersebut menampilkan tentang tema cerita rakyat asli Indonesia dari daerah Ponorogo, Bali dan Flores seharusnya model pria yang dipilih sebagai objek visual harus dapat merepresentasikan cerita rakyat Indonesia atau salah satu dari cerita rakyat yang terdapat dalam pilihan acara tersebut namun desainer malah memilih kostum yang identik dari budaya luar.

Dari sudut pandang ini dapat dinilai bahwa desainer dari poster tersebut memang berpengalaman dalam teknik dan skill dalam mengorganisasi visual, namun sayangnya, desainer kurang berpengalaman dalam hal komunikasi visual. Desainer dari poster tersebut kurang dalam hal riset mengenai budaya-budaya asli Indonesia dan kurangnya riset mengenai psikologi, sosiologi yang berdampak pada desain.

Sekilas, karya poster yang dirancang terkesan baik-baik saja bahkan menarik, namun karya poster yang dirancang memiliki dampak yang sangat fatal. Dampak yang fatal tersebut antara lain adalah bahwa akan adanya anggapan dari masyarakat yang membaca poster tersebut bahwa model pria yang mengenakan riasan kepala khas Suku Indian tersebut adalah bagian dari budaya Indonesia karena terdapat penjelas berupa tulisan "Indonesian Folklore" padahal kenyataanya tidak seperti itu.

Masalah diatas juga dapat dikatakan bahwa masih banyak masyarakat Indonesia yang masih bangga dan masih menggangap keren budaya luar. Dapat dilihat dari peilihan kostum model pria tersebut.

Dari masalah diatas dapat diambil pelajaran bahwa mendesain komunikasi visual itu tidak hanya membuat sebuah organisasi visual agar terlihat menarik saja, namun juga harus dipertimbangkan serta harus dipehitungkan unsur komunikasi agar pesan yang tersampaikan tidak mengalami miskomunikasi. Diperlukannya metode dan pemetaan pikiran yang matang agar proses berjalannya pesan tidak mengalami miskomunikasi yang dapat berpengaruh besar bagi pembaca atau khalayak sasaran baik berpengaruh pada pikiran, perilaku bahkan karakter.

\section{SIMPULAN}

DKV merupakan sebuah ilmu untuk mengkomunikasikan sebuah pesan kepada khalayak sasaran dengan pengorganisasian unsur-unsur visual seperti elemen grafis dan elemen tipografi. Dalam DKV, visual merupakan hal yang penting, namun visual 
tidak menentukan keberhasilan akan karya desain yang dirancang, perlu adanya komunikasi yang sesuai dengan pesan yang ingin disampaikan, karena pada dasarnya DKV adalah ilmu komunikasi dengan pengorganisasian elemen-elemen visual sebagai bahasanya.

Perlu metode-metode dan pemetaan pikiran (mind-map) yang matang untuk menghasilkan karya desain yang baik. Selain itu juga desainer perllu menambah wawasan keilmuan seperti sejarah, psikologi, sosiologi, pemasaran dan lain-lain dengan harapan agar meluaskan pandangan para desainer dalam proses merancang sebuah desain.

Desainer yang kurang menimba ilmu dan memperluas wawasan dapat menyebabkan karya desain yang dirancang berpotensi menjadi miskomunikasi. Miskomunikasi dapat berpotensi menjadi membahayakan dikarenakan DKV itu sendiri digunakan sebagai salah satu media konstruksi sosial. Salah satu contoh miskomunikasi visual dalam DKV adalah Poster story Instagram dari acara Gelar Cipta Tata Rias 2019 yang bertemakan "Indonesian Folklore". Dalam poster tersebut terdapat sebuah miskomunikasi yang dapat menyebabkan kesalahan fatal bagi bangsa Indonesia karena model pria yang djadikan elemen visual pendukung poster memakai kostum riasan kepala khas suku Indian Amerika, sedangkan acara tersebut merupakan acara yang bertemakan cerita rakyat Indonesia.

Kesimpulan dari masalah miskomunikasi visual diatas adalah bahwa harusnya seorang desainer selain melatih kemampuan untuk mengolah visual juga desainer harus peka terhadap proses komunikasi,

bagaimana mengkomunikasikan, teknik komunikasi dan strategi komunikasi agar pesan yang disampaikan tepat sasaran dan tidak terjadi miskomunikasi.

\section{KEPUSTAKAAN}

[1] Bahari, Nooryan. (2008). Kritik SeniL Wacana, Apresiasi dan Kreasi. Yogyakarta: Pustaka Pelajar.

[2] Frascara, Jorge. (2004). Communication Design: Principles, Method, and Practice. Allworth Press .

[3] Kusrianto, Adi. (2009). Pengantar Desain Komunikasi Visual. Yogyakarta: Penerbit Andi.

[4] Supriyono, Rakhmat. (2010). Desain Komunikasi Visual, Teori dan Aplikasi.Yogyakarta: Penerbit Andi.

[5] Tinarbuko, Sumbo. (2015). Dekave: Desain Komunikasi Visual Penanda Zaman Masyarakat Global. Yogyakarta: Penerbit CAPS.

\section{Webtografi}

[1] Emir. (2019). Usung Tema Folklore dalam Show time Gelar Cipta Tata Rias 2019. diakses 8 Juni 2019, dari https://www.unesa.ac.id/usung-temafolklore-dalam-show-time-gelar-ciptatata-rias-2019\# 